
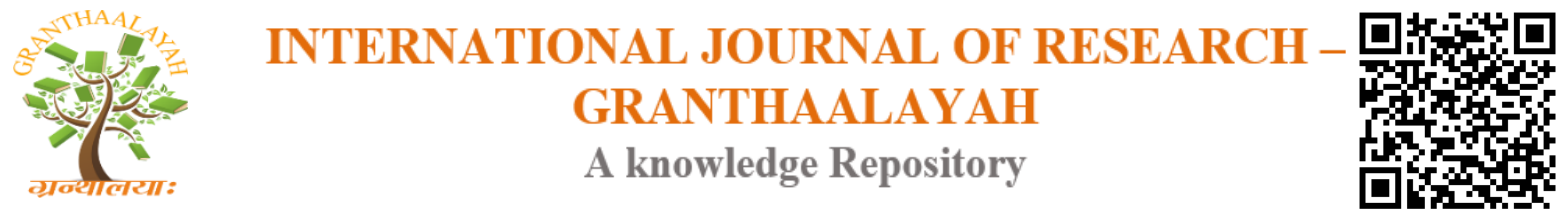

Social

\title{
TEACHERS' USE OF INFORMAL FORMATIVE ASSESSMENT IN SENIOR SECONDARY SCHOOL CHEMISTRY CLASSROOMS IN SWAZILAND
}

\author{
Mzenzi S. Masuku ${ }^{1}$, O I. Oloyede ${ }^{2}$, Victoria L. Kelly ${ }^{3}$ \\ ${ }^{1}$ National Curriculum Centre, Box 73 Manzini, Swaziland \\ ${ }^{2,3}$ University of ESwatini, Department of Curriculum and Teaching, P/B 4 Kwaluseni,
}

Swaziland

\begin{abstract}
The social-economic role of education as a major driver of human development calls for quality education that is rooted on effective teaching and learning. While Swaziland aspires to have products of her secondary education system efficiently joining tertiary training or the workplace, the SGCSE performance trend in Physical Science currently features below expectation. This study explored how teachers in Swaziland used informal formative assessment in their senior secondary school Chemistry lessons. Three purposively sampled lessons from Form 4 and Form 5 were observed. Data were collected through field notes and analysed using inductive content analysis. Findings showed that teachers used informal formative assessment by explaining misunderstood content in fresh ways, giving learners remedial work, initiating hand-clapping, repeating or adjusting initial and probing questions. All in all, teachers used informal formative assessment in line with standard practices though they often resorted to telling learners answers to seemingly demanding questions.
\end{abstract}

Keywords: Informal Formative Assessment; Feedback; Chemistry Learning; Swaziland.

Cite This Article: Mzenzi S. Masuku, O I. Oloyede, and Victoria L. Kelly. (2019). "TEACHERS' USE OF INFORMAL FORMATIVE ASSESSMENT IN SENIOR SECONDARY SCHOOL CHEMISTRY CLASSROOMS IN SWAZILAND." International Journal of Research - Granthaalayah, 7(1), 348-360. https://doi.org/10.29121/granthaalayah.v7.i1.2019.1062.

\section{Introduction}

Human development has received greater attention from world societies these days based on the premise that it is one of the strategies through which sustainable socio-economic upturns can be attained. At the heart of the human development initiative there is education, which can be viewed from the "access" and the "quality" aspect (UNDP, 2014). Swaziland has already reported a 95.6\% achievement of access to primary education (UNESCO, 2015). While this is worth celebrating, the presence of large numbers in classrooms does not automatically imply that learners are exposed to quality learning experiences. 
Swaziland's definition of quality education is that education should enhance learners' personal development and contribute to Swaziland's cultural development, socio-economic growth and global effectiveness (Ministry of Education and Training, 2011). The Ministry of Education and Training has also officially launched and adopted the fourth Sustainable Development Goal of striving to ensure an inclusive, equitable quality education, and lifelong learning for all by year 2030. Contemporary approaches to learning emphasise the development of knowledge and understanding through talk and inquiry (Sampson \& Blanchard, 2012). These modern views to learning argue for teaching that builds its pace and direction on learners' preconceptions within an environment that promotes knowledge construction (Alexander, 2006).

This teaching paradigm dictates that the teacher influences learning, by first getting a sense of how learners think using their prior knowledge and current experiences (Brookhart, 2008). This learning precondition, therefore, underscores the necessity for a means of instantaneously eliciting what learners have already learnt or have not, during the learning process. Such an assessment that occurs within the learning process with the purpose of improving learning is referred to as formative assessment (Black \& Wiliam, 2009). Formative assessment can either be formal, if planned, or informal, if unplanned (Bell \& Cowie, 2001).

Informal assessment mainly consists of instructional dialogues which make learners' thinking explicit in an unobtrusive way. When learners' thinking is definite and clear, it can be examined, interrogated, and moulded as an object of constructive learning (Ruiz-Primo, 2011). With such a high number of informal assessments in the classroom context, how they are used and how they collectively affect learning cannot be downplayed.

Formal basic education in Swaziland spans over 12 years through the 7-3-2 year system that is aligned to three levels: Primary, Junior Secondary, and Senior Secondary level. At the primary school level learners follow a general science curriculum, while at the Junior secondary school level they do integrated science, among other subjects. Integrated Science comprises Biology, Chemistry and Physics offered in relatively equal content proportions. In the last two years of the secondary school education learners do either Biology or Physical Science or both because science is regarded as a core subject at this level. These two years culminate in the writing of the Swaziland General Certificate of Secondary Education (SGCSE), a localised version of the International General Certificate of Secondary Education (IGCSE).

The SGCSE curriculum consists of core and elective subjects. The core subjects provide learners with essential skills such as communication and problem-solving skills. These core skills are developed through English, siSwati, Mathematics and Science. The Science offered to learners can either be Biology or Physical Science or both. Physical Science is offered in two sections: Section A contains the Physics content and Section B, the Chemistry content. According to the SGCSE curriculum, learners that are adequately prepared for tertiary education are those that have achieved Grade C or better in at least four subjects: siSwati, English Language, Mathematics and Science (Biology or Physical Science).

The national aspiration reflected in the Education Sector Policy of 2011 describes the envisaged product of the secondary education system as a learner who is able to smoothly join the place of work or enroll for further training. The SGCSE curriculum describes that learner as one who has 
obtained Grade $\mathrm{C}$ or better at least in Physical Science, since it supports essential skills. The national performance in Physical Science does not only perpetually feature below $24 \%$ of C grades or better, its average over the last three years ranks below each of the other core subjects'. Literature, however, shows that significant learning gains are achievable through effective formative assessment practices, more significantly with low achievers (Black \& Wiliam, 2009). It is against this backdrop that this study sought to establish how informal formative assessment information is used by teachers in Physical Science classrooms. The study was guided by the question: how do teachers use informal formative assessment as they teach Chemistry?

\section{Informal Formative Assessment and Learning}

Assessment, teaching and learning are concurrent and complementary processes that serve a common purpose (Ruiz-Primo \& Furtak, 2007). This purpose is often called the learning goal, which teachers derive from the curriculum (Brookhart \& Moss, 2015). The Learning goal does not only form the basis for teaching, but also for assessment and learning. In other words, the learning goal has implications for the teacher as an educator, as an assessor, and for the learner as a participant in the learning process (Wiliam \& Leahy, 2007). Assessment can also be classified as informal if it is unplanned or formal if it is planned before the lesson (Bell \& Cowie, 2001).

The term "informal" does not necessarily refer to the naturally unpredictable events that arise in any classroom, but rather to the small scale, frequent opportunities teachers have for collecting information about students' progress towards the learning goals (Ruiz-Primo, 2011). Such opportunities due to the social nature of classroom activities, are predominantly availed through instructional dialogues that are also known as assessment conversations (Tuan \& Nhu, 2010; Muhonen, Rasku-Puttonen, Pakarinen, Pikkeus, \& Lerkkanen, 2016; Tuan \& Nhu, 2010). Assessment conversation become effective if the teacher adopts an attitude characterised by the desire to continuously learn about learners' learning, to routinely use the evidence gathered to decide what to do next, and consider how pedagogical practices are shaping the learning process (Moss, 2008).

There are several theories that explain how people learn. Behaviourist theories maintain that learning relies on the nature of the external stimulus provided to the learner. They believe in the inductive approach to learning in that before general ideas are developed, specific units within those ideas need to be thoroughly mastered to generate speedy performances (Bilal, 2006). Behaviourism is seen in assessment when convergent questions are asked (Tuan \& Nhu, 2010). Convergent questions are those where the answer to the question is known to the teacher before the question is asked. Such evaluations lend themselves to right or wrong answers with no inbetweens.

Learning to the constructivist is a process of creating personal meaning from new information and prior knowledge (Kang, Thompson, \& Windschitl, 2014). Proponents of constructivism outline two main views of this approach. Cognitive constructivists argue that personal reflection on experiences leads to learning. This line of thinking is mostly influenced by the works of Jean Piaget. Social Constructivists, on the other hand, contend that learning occurs between individuals so that negotiated meaning is arrived at. In his three hypotheses Krashen (1985) argues that meaning can be reached through language input, intake and output. In Krashen's view language input occurs when learners read or listen to speech that carries the message (Tuan \& Nhu, 2010). 
Social Constructivism, therefore, highlights the significance of another person besides the learner, whom Vygotsky referred to as an adult, in the learning process. In the classroom environment this "adult" can be the teacher or peers.

Classroom talk, as a major episode of informal formative assessment, in such cases becomes vital. Informal formative assessment's importance is justified by the fact that through oral interactions teachers and peers influence learners' thoughts on the interpsychological plane before meaning is finally constructed by the learner personally on the intrapsychological plane (Gamlem \& Munthe, 2014). This occurs within Vygotsky's Zone of Proximal Development (ZPD) where formative assessment enables the learners to solve problems they could not solve without teacher or peer assistance (Vygotsky, 1978).

\section{Formative Feedback}

Feedback based on the monitoring of learning is essential for effective teaching and learning, because it enhances and sustains the relevance of the learning process (Bremner, 2014). According to Shirley (2009)'s model of the conceptualisation of formative assessment (Error! Reference source not found.), the teacher's monitoring tools are instructional tasks and questions.

Table 1: Adapted Conceptual Model of Formative Assessment (Shirley 2009)

\begin{tabular}{|c|c|c|c|c|c|}
\hline & \multicolumn{4}{|c|}{ Aspect of Formative Assessment } & \multirow{2}{*}{$\begin{array}{l}\text { Hypothesised } \\
\text { Outcome }\end{array}$} \\
\hline & $\begin{array}{l}\text { Instructional Task } \\
\text { Implementation }\end{array}$ & $\begin{array}{l}\text { Questioning for } \\
\text { understanding }\end{array}$ & $\begin{array}{c}\text { Teacher } \\
\text { Awareness of } \\
\text { learning needs }\end{array}$ & $\begin{array}{c}\text { Teacher } \\
\text { Repertoire of } \\
\text { strategies (CK } \\
\text { and PCK) }\end{array}$ & \\
\hline \multirow{4}{*}{ 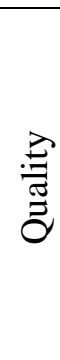 } & Cursory & Weak & No & $\begin{array}{l}\text { No data to base } \\
\text { strategies on }\end{array}$ & $\begin{array}{l}\text { No improvement } \\
\text { in learning }\end{array}$ \\
\hline & Rich & Deep & Yes & Insufficient & $\begin{array}{l}\text { Learning not } \\
\text { improved }\end{array}$ \\
\hline & Cursory & Deep & Some & $\begin{array}{l}\text { Partial data to } \\
\text { base strategies on }\end{array}$ & $\begin{array}{l}\text { Some Learning } \\
\text { Improvement }\end{array}$ \\
\hline & Rich & Deep & Yes & Yes & $\begin{array}{l}\text { Learning } \\
\text { Improved }\end{array}$ \\
\hline
\end{tabular}

Through this model, Shirley posits that exposing learners to rich instructional tasks and deep questioning enables the teacher to be aware of learners' needs. These needs serve as feedback to the teacher who then crafts them in a language that is understandable to the learner as feedback to give to the learner.

Both teachers and learners have roles to play in responding to the learners' needs. Effective use of formative assessment feedback by both teachers and learners produces significant learning gains, notably among medium and low achievers (Black \& Wiliam, 2009). The effective use of feedback occurs where teachers and learners both learn during the feedback-giving process (Brookhart \& Moss, 2015), but the teacher needs to be a leading learner, not just the distributor of education wisdom (Brookhart \& Moss, 2013). The teacher's leading role is seen when questions are asked. The quality of feedback, according to these authors is considered adequate if it is descriptive, timely, appropriate, criterion-based, task-based, intelligible and positive, and specific but not too specific, and communicated through the right tone. 
The learning process dictates that teachers continually seek ways of making sense of learners' responses, actions and comments which compel the teacher to make decisions about the direction and nature of subsequent instructional activities (Gamlem \& Munthe, 2014). The efficiency of the teacher's decision making process then hinges on the quality of their pedagogical strategies (Shirley, 2009).

The formative assessment cycle generally repeats after feedback is fully given to the learner, forming the Question-Response-Feedback (QRF) sequence (Gamlem \& Munthe, 2014; Shirley, 2009). A specific version of this cycle is the informal formative assessment cycle which embraces the same rationale as the QRF process, but differs in that it includes the step of acknowledging (recognising) the learners' response. This model involves teachers eliciting learners' current understanding, students responding, teacher recognising the response, and teacher using the response (ESRU) (Ruiz-Primo \& Furtak, 2007).

In his study Ruiz-Primo (2011) found that offering explanations was one of the critical scaffolding strategies. Explanations that best serve as scaffolds are those that address why something is important, when it is used, and how it is used. Kippers, Schildkamp, and Poortman (2016) in the Netherlands explored the use of formative assessment by teachers in secondary schools. These researchers found that secondary school Dutch teachers provided both oral and written feedback to learners by addressing misconceptions through explaining learning content to learners in another way, by repeating the same instruction, by calling parents, and urging students to do more practice and come for extra lessons.

In Britain, William(2015)'s findings were consistent with Kipper et al (2016)'s but his had a warning that assuming students do know something when they actually don't is far more serious than assuming they do not know something when, in fact, they do. His experimental study on informal formative assessement strategies argued in favour of asking strategic and reliable oral questions within a short space of time to the entire class (which he referred to as hinge questions) before moving on with the lesson.

In China, Jiang (2014) explored the effectiveness of oral questioning as an informal formative assessment strategy. Data were collected through lesson observations and interviews and the findings indicated that oral questions were effective scaffolds for learning. Ruiz-Primo (2011) in his position paper on the significance of instructional dialogues within the United States setting, contended that higher order, Socratic, open-ended questions be used as a way of starting and continuing assessment conversations.

Formative assessment in general has been researched by several authors in Swaziland Secondary schools. Dlamini (2014), for instance, explored how Form 4 History teachers used formative assesment. He found that testing (a formal formative assessment technique) dominated the methods used, and he was able to establish that the quality of the oral feedback given to learners was extremely low with regard to tone and relevance to the task. Not much inquiry, however, on local senior Secondary Chemistry teachers' use of informal formative assessment has been documented. 


\section{Research Methodology}

This study was rooted on the qualitative inquiry approach. To answer the question that guided the study, a multiple case study design was adopted. The population of this study was all Senior Secondary Physical Science teachers in Swaziland. Three teachers in the Manzini Region were purposively sampled.

\section{Research Instruments and Data Collection}

Lesson observations were conducted for each of the three schools on separate days during which descriptive notes were recorded in field notebooks as the lesson progressed. The field notes were later-converted into computerised transcripts and consolica with audio recording.

Prior to observing the lesson, the researcher conducted pre-lesson interview to get a sense of the lesson organisation, learners' engagement during the lesson and the nature of planned learner activities. As soon as the lesson started the researcher turned on the audio recorder. The researcher took on a participant observer role during lesson observations. The researcher sat at the back of the class to minimise interference with lesson processes, and only moved around to probe learners reasoning as they worked on group tasks or individual tasks through asking probing oral questions. Soon after observing the lesson the researcher held a brief talk with each of the participants to share experiences from the lesson. The teachers summarised their experiences by highlighting major lessons learnt from the lesson. The researcher then outlined the contents of the field notes and inquired if the record reflected what transpired during the lesson. Identified discrepancies were resolved by consensus.

\section{Data Analysis}

Transcripts of field notes were numbered line by line based on assessment moves made by both teacher and learner. An inductive content analysis approach was pursued beginning with reading through the data several times before creating categories of meaning. The two co-researchers were then asked to read through the data and draw their own categories before researchers' categories were compared and areas of disparity resolved through a consensus.

\section{Results, Findings and Discussion}

The characteristics of the teachers (T1, T2, and T3) who participated in the study are summarised in Table 2 below.

Table 2: Characteristics of T1, T2 and T3

\begin{tabular}{|l|l|l|l|}
\hline Feature & T1 & T2 & T3 \\
\hline School location & Urban & Urban & Peri-Urban \\
\hline Qualifications & B.Ed. Sec. & B.Ed. Sec. & B.Sc. + PGDE \\
\hline Classes taught & Form 4 and 5 & Form 4 and 5 & Form 4 and 5 \\
\hline Class size & 46 pupils & 33 pupils & 48 pupils \\
\hline Physical Science Teaching Experience & 7 years & At least 15 years & At least 15 years \\
\hline SGCSE marking Experience & 5 years & None & None \\
\hline
\end{tabular}


Table 2 shows that all three teachers either taught at an urban or peri-urban school, and T1 and T2 both had a Bachelor of Education in Secondary Science, while T3 had a Bachelor of Science and a Post Graduate Diploma in Education. While all three teachers taught both Form 4 and Form 5, their class sizes differed. T1 had the least teaching experience of 7 years yet highest (5 years) SGCSE marking experience among the three teachers. The other two teachers had taught for at least 15 years and had no SGCSE marking experience.

\section{Research Question: How do Teachers Use Informal Formative Assessment During Their Lessons?}

To establish how teachers used informal formative assessment in their lessons, each lesson was divided into three episodes that emerged from the categories of the collected data. These were: lesson organisation, ways in which learners engaged in activities and the activities that the learners did.

\section{Lesson Organization}

Through the teachers' efforts to organise their lessons, informal formative assessment (IFA) was noticed and observed and the emerging themes are recorded in Table 3. During the general organisation of the lesson, teachers used informal formative assessment in the following ways:

\section{Proactive Remediation}

Proactive remediation occurred where the teacher gave remedial comments and requested the learner to work on and submit a corrected version of the work.

\section{Probing for Understanding Gaps}

Probing for understanding gaps occurred when the teacher asked a further question in trying to understand what the learner understood and where they still needed help. Once the learning need was establish the teacher addressed it through further initiatives such as remediation.

\section{Recognition of Prior Knowledge}

Recognition of prior learning happened when the teacher highlighted strengths and weaknesses within the learner' response and explained misunderstood content in another way. The link between the preconceptions and the current learning goal were later clarified. This happened at the beginning of the lesson during the review of the previous lesson.

\section{Oral Approval}

Oral approval occurred when the teacher responded to learners' oral attempts by making approving comments such as "good", "excellent" or invited the class for applause.

Table 3: Analysis of IFA use in Lesson Organisation

\begin{tabular}{|l|l|l|}
\hline Code & Statement from Field Notes & Categories \\
\hline PR & $\begin{array}{l}\text { T3 responded to the learners' oral homework } \\
\text { presentation by asking for the class' reaction, } \\
\text { evaluated the class feedback and clarified grey } \\
\text { areas, then asked the learners to do write } \\
\text { corrections. }\end{array}$ & $\begin{array}{l}\text { Remedial comments were given } \\
\text { and learners made to do written } \\
\text { corrections }\end{array}$ \\
\hline
\end{tabular}




\begin{tabular}{|c|c|c|}
\hline Code & Statement from Field Notes & Categories \\
\hline PR & $\begin{array}{l}\text { T2 gave an incomplete answer and asked learners } \\
\text { to complete it after learners had given no response } \\
\text { to the question. }\end{array}$ & \\
\hline PUG & $\begin{array}{l}\text { T3 after seeing a face frown due to a question that } \\
\text { was posed earlier on asked the learner a further } \\
\text { question "does the question worry you?" }\end{array}$ & \multirow{4}{*}{$\begin{array}{l}\text { Probing for Understanding Gaps } \\
\text { Asked a further question for } \\
\text { understanding learning need, } \\
\text { which got addressed through e.g } \\
\text { remediation. }\end{array}$} \\
\hline PUG & $\begin{array}{l}\text { T2 asked a further question in response to learners' } \\
\text { responses to the initial question }\end{array}$ & \\
\hline PUG & $\begin{array}{l}\text { T1 confirmed a learner's response "A halogen is a } \\
\text { group } 7 \text { element" by saying "correct!" and further } \\
\text { asked the class for the meaning of the term "group } \\
7 \text { elements" }\end{array}$ & \\
\hline$\overline{P U G}$ & $\begin{array}{l}\text { T3 responded to facial frowns by asking follow-up } \\
\text { questions that landed themselves to remediation } \\
\text { during extra time. }\end{array}$ & \\
\hline RPK & $\begin{array}{l}\text { T2 asked learners if they remembered the } \\
\text { conditions under which ionic compounds conduct } \\
\text { electricity. One learner responded: "When they are } \\
\text { in a circuit, sir". As a follow up T2 commented } \\
\text { "yes, but let us set one ionic compound in a } \\
\text { circuit." T2 then took dry sodium chloride and } \\
\text { connected it and there the bulb in the circuit did } \\
\text { not light up and only turned on, after they used the } \\
\text { salt in solution form. }\end{array}$ & $\begin{array}{l}\text { Recognition of Prior Knowledge } \\
\text { RPK) } \\
\text { Recognition of prior learning } \\
\text { resulted from when the teacher } \\
\text { highlighted strengths and } \\
\text { weaknesses within the learner' } \\
\text { response and explained } \\
\text { misunderstood content in another } \\
\text { way. }\end{array}$ \\
\hline $\mathrm{OA}$ & $\begin{array}{l}\text { T1 acknowledged the learner's response to the } \\
\text { description of group } 7 \text { elements by saying } \\
\text { "Excellent" and invited applause from the class." }\end{array}$ & $\begin{array}{l}\text { Oral Approval Teacher invites } \\
\text { Class applause or gives an } \\
\text { approving comment }\end{array}$ \\
\hline
\end{tabular}

\section{Ways in Which Learners Engaged in Activities}

As the teachers taught through engaging learners in the various activities of the lesson, informal formative assessment was noticed and observed sections with the emerging themes are recorded in Table 4. The teachers engaged their learners in the class activities in different ways. Informal formative assessment as the learners were engaged in these activities was used in the following ways:

\section{Proactive Remediation}

Proactive Remediation happened when the teacher kept track of the learners' responses in order to establish the learning need. In response to the identified learning need, the teacher then described an analogy or illustrative example to guide the learner's thinking towards the answer.

\section{Treating Own Question}

The treatment of the teacher's own question was noticed after learners gave no response to a question that the teacher asked. The teacher then rephrased his initial question or repeated the question or told learners the correct answer. 


\section{Oral Approval}

Oral approval occurred when the teacher responded to learners' oral attempts by making approving comments such as "good", "excellent" or inviting the class for applause.

Table 4: Analysis of IFA use in learner involvement

\begin{tabular}{|l|l|l|}
\hline Code & Statement from the field notes & Categories/Themes \\
\hline OA & $\begin{array}{l}\text { T3 requested the class to applaud the } \\
\text { correct answer, after a learner had given the } \\
\text { correct answer through the oral homework } \\
\text { presentation. }\end{array}$ & $\begin{array}{l}\text { Oral Approval Teacher invites Class } \\
\text { applause or gives an approving comment. }\end{array}$ \\
\hline PR & $\begin{array}{l}\text { T2 examined learners' frowning faces at } \\
\text { the sight of the sample of the Sodium }\end{array}$ & $\begin{array}{l}\text { Proactive Remediation } \\
\text { Chloride he was displaying, and then told } \\
\text { them the common name for Sodium }\end{array}$ \\
$\begin{array}{l}\text { Chloride, before inviting the learner to taste } \\
\text { the chemical. }\end{array}$ & $\begin{array}{l}\text { learning need, then describe an analogy or } \\
\text { illustrative example or assign task, to } \\
\text { guide the learner's thinking towards the } \\
\text { answer. }\end{array}$ \\
\hline TOQ & $\begin{array}{l}\text { T2 responded "It conducts electricity!" } \\
\text { after learners remained silent to the } \\
\text { question "what does the lighting of the bulb } \\
\text { mean about the solution?" }\end{array}$ & $\begin{array}{l}\text { Treating own Question } \\
\text { Rephrasing or Repeating the question or } \\
\text { telling learners the correct answer after } \\
\text { they fail to respond to a question. }\end{array}$ \\
\hline TOQ & $\begin{array}{l}\text { T1 repeated the question "How does the } \\
\text { reactivity of halogens change as you go } \\
\text { down the group?" after learners failed to } \\
\text { give a response. }\end{array}$ & \\
\hline
\end{tabular}

\section{Activities in Which Learners Were Engaged}

As the teacher facilitated the activities during the lesson, informal formative assessment was noticed and the observed sections with the emerging themes are recorded in Table 5.

The nature of the activities the teachers engaged their learners in, created opportunities for informal formative assessment to be used in the following ways:

\section{Treating own Question}

In cases where the learners experienced some difficulty of understanding the question the teacher either rephrased or repeated the question. When the learners could not respond to the question the teacher told them the correct answer.

\section{Probing for Understanding Gaps}

Probing for understanding gaps occurred when the teacher asked a further question for a better understanding of the learner's challenge. The challenge then got addressed through further teacher initiatives such as remediation.

\section{Proactive Remediation}

Proactive remediation occurred when the teacher monitored the learners' responses by asking follow up questions. He then described an analogy or illustrative example to guide the learner's thinking towards the answer. 


\section{Oral Approval}

Oral approval occurred when the teacher responded to learners' oral attempts by making approving comments such as "good", "excellent" or invited the class to give applause.

Table 5: Analysis of IFA use in Learner Activities

\begin{tabular}{|c|c|c|}
\hline Code & Statement from the field notes & Category/Theme \\
\hline TOQ & $\begin{array}{l}\text { T3 repeated the question after learners were } \\
\text { silent to it. }\end{array}$ & \multirow{3}{*}{$\begin{array}{l}\text { Treating own Question } \\
\text { Rephrasing or Repeating the question or } \\
\text { telling learners the correct answer after } \\
\text { they fail to respond to a question. }\end{array}$} \\
\hline TOQ & $\begin{array}{l}\text { T3 slowed down his speech when he was } \\
\text { asking the question for the second time }\end{array}$ & \\
\hline TOQ & $\begin{array}{l}\text { T3 Rephrased the question as he repeated it } \\
\text { a third time following continued silence }\end{array}$ & \\
\hline OA & $\begin{array}{l}\text { T3 gave the evaluative comment "good" to } \\
\text { a learner's definition of ionic compounds. }\end{array}$ & $\begin{array}{l}\text { Oral Approval Teacher invites Class } \\
\text { applause or gives an approving comment. }\end{array}$ \\
\hline \multirow[t]{2}{*}{ PUG } & \multirow{2}{*}{$\begin{array}{l}\text { T2 responded to the student's question "are } \\
\text { all electrodes made of metal?" by asking a } \\
\text { further question "What would happen if an } \\
\text { electrode made of sodium metal were } \\
\text { dipped into an aqueous solution?" }\end{array}$} & Probing for Understanding Gaps \\
\hline & & $\begin{array}{l}\text { Asked a further question for } \\
\text { understanding learning need, which got } \\
\text { addressed through e.g remediation }\end{array}$ \\
\hline \multirow[t]{2}{*}{ PR } & T2 responded to the silence to the question & \multirow{3}{*}{$\begin{array}{l}\text { Proactive Remediation } \\
\text { Monitored the learners' response for } \\
\text { learning need, and then describe an } \\
\text { analogy or illustrative example or } \\
\text { practice to guide the learner's thinking } \\
\text { towards the answer. }\end{array}$} \\
\hline & $\begin{array}{l}\text { "What would happen if ...?" by citing an } \\
\text { illustrative and critical incident from the } \\
\text { daily news about a science class in the } \\
\text { country. }\end{array}$ & \\
\hline PR & $\begin{array}{l}\text { T1 gave a consolidation classwork } \\
\text { following the learner's response that } \\
\text { illustrated an emerging understanding of the } \\
\text { displacement of reactions. }\end{array}$ & \\
\hline
\end{tabular}

All in all, teachers used informal formative assessment to recognise prior learning, to provide proactive remediation, to treat the teacher's own questions, to probe for understanding learning gaps, and to give oral approval.

\section{Discussion of Findings}

Teachers recognised prior learning through mentioning strengths and areas of improvement from learners' responses, and explained the misunderstood content in another way. The practical demonstration with instructional dialogues that $\mathrm{T} 2 \mathrm{used}$, for instance, led learners to drawing the desired conclusions on their own. This finding is consistent with Kippers, Schildkamp, and Poortman (2016)'s findings that indicated that teachers addressed misconceptions through explaining content in different ways.

In addition, Ruiz-Primo (2011) found that offering explanations was one of the critical scaffolding strategies. While these studies indicated that oral explanations best serve as scaffolds if they address why something is important, when it is used, and how it is used. In the current study T1 and T3's approaches to clarifying misconceived content were consistent with Ruiz-Primo's 
finding, but T2 achieved the same goal through a practical demonstration facilitated with dialogues, which is a more innovative approach than most conventional teaching methods.

The recognition of prior learning by first eliciting it through informal formative assessment at the start of the lesson is consistent with the philosophy of constructivism. Brookhart and Moss (2015) insist that new knowledge construction is only effective if it is made relevant to prior knowledge and experiences.

Informal formative assessment was also used to attend to the teachers' initial questions. This occurred after learners failed to respond to the posed question. The teachers' responses involved telling the students the answer or repeating the question at the original or slower pace, and rephrasing the question. According to Ruiz-Primo (2011) rephrasing, clarifying, elaborating, summarising and repeating a question is a way of offering an explanation of what the question means, and it serves as a helpful scaffolding strategy. It can thus be inferred that by repeating and slowing down the question the teacher offered a way for learners to understand the question better. Telling the students the answer in response to their silence, in the light of Shirley (2009)' s model (Table 1), demonstrates a weak effort (as a matter of fact, no effort at all) to question learners for understanding, based on their engagement with an instructional task. Shirley (2009) then argues through her model that the teacher then fails to be aware of the learning need, which ultimately makes the selection and use of relevant teaching strategies impossible since there would be no information to base the strategy on. In the end no learning improvement occurs. It can thus be inferred that though repeating, slowing down or rephrasing a question symbolised good informal formative assessment practice, telling students the answer in response to their failure to respond to a question attracted no learning gain.

The provision of proactive remediation generally refers to the contigent teaching and learning that is motivated by the formative assessment outcome. The teachers in this study used oral explanations then made learners do assigned work such as corrections and consolidation classwork. Gamlem and Munthe (2014) uses the term "moments of contingencies" to describe the teachers' response at this stage of the learning process. Shirley (2009) argues that if this part is done from a rich repertoire of pedagogical strategies chances for improved learning are increased. The teachers also probed learners reasoning through asking a further question when learners were expecting an evaluative feedback for their attempts. According to Ruiz-Primo and Furtak (2007) the informal formative assessment cycle involves the four stages commonly known as ESRU. By asking a further question the teachers had recognised the learner's response and used it to pose a further question. It is quite likely the teacher sought a deeper understanding of what the learner had understood and what they had not. In other words the teachers used informal formative assessment through the ESR-ESR... cycles instead of a single ESRU cycle.

Teachers in this study also used informal formative assessment to provide oral approval through statements like "good", "Excellent" or prompt the class to applaud a response. This type of feedback according to Brookhart and Moss (2015), and Gamlem and Munthe (2014) has limited quality. The quality of feedback, according to these authors is considered adequate if it is descriptive, timely, appropriate, criterion-based, task-based, intelligible and positive, and specific but not too specific, and communicated through the right tone. We can therefore infer, that the 
teacher gave oral feedback of low quality in that it was not descriptive enough and had limited specificity on the pertinent sections within the task.

\section{Conclusion}

From the findings of the study, it can be concluded that teachers used informal formative assessment in line with standard informal formative assessment practices though they often resorted to telling learners answers to seemingly demanding questions. In-service workshops focusing on probing skills are recommended for these teachers.

\section{References}

[1] Alexander, R. (2006). Towards Dialogic Teaching: Rethinking Classroom Talk. Cambridge: Dialogos.

[2] Bell, B., \& Cowie, B. (2001). The Characteristics of Formative Assessment in Science Education. Science Education, 536-553.

[3] Bilal, G. (2006). The Nature of Reflective Thinking and Its Implications for In-Service Teacher Education. Istanbul: Cukurova University.

[4] Black, P., \& Wiliam, D. (2009). Developing the Theory of Formative Assessment. Educational Assessment, Evaluation and Accountability, 21, 5-31.

[5] Bremner, A. L. (2014). Teachers' Knowledge of Formative Assessment Initial Instrument Validity Study. Unpublished PhD Dissertation. Boise State University. Boise.

[6] Brookhart. (2008). How to give Effective Feedback to your Students. Alexandria, VA: Association of Supervision and Curriculum Development.

[7] Brookhart, S., \& Moss, C. (2013). Leading by learning. Phi Delta Kappan, 94(8), 13 - 17.

[8] Brookhart, S., \& Moss, C. (2015, September). How to Give Professional Feedback. Educational Leadership, 72(7), pp. 24-30.

[9] Dlamini, M. (2012). Formative Assessment Practices of Secondary School History Teachers in Swaziland and Their Contribution To Learners Understanding. Unpublished Masters' Thesis, University of Swaziland, Kwaluseni.

[10] Gamlem, S. M., \& Munthe, E. (2014). Mapping Feedback to Support Students' Learning in Lower Secondary Classroooms. Cambridge Journal of Education, 44(1), 75-92.

[11] Kang, H., Thompson, J., \& Windschitl, M. (2014). Creating Opportunities for Students to Show What They Know: The Role of Scaffolding in Assessment Tasks. Science Education, 98(4), 674704. doi:10.1002/sce. 21123

[12] Kippers, W., Schildkamp, K., \& Poortman, C. (2016). The Use of Formative Assessment by Teachers in Secondary Education in the Netherlands. Washington: AERA.

[13] Mack, N., Woodsong, C., MacQueen, K., Guest, G., \& Namey, E. (2011). Qualitative Research Methods: A Data Collector's Field Guide. United States of America: Family Health Internations 360 .

[14] Masuku, M. (2016). Teachers' Use of Formative Assessment in Secondary Schools Chemistry Learning in Swaziland. Unpublished Masters Thesis, University of Swaziland, Kwaluseni, Swaziland.

[15] McMillan, J., \& Schumacher, S. (2014). Research in Education - Evidence Based Inquiry. London: Pearson.

[16] Ministry of Education and Training. (2011). Education Sector Policy. Mbabne: Swaziland Government.

[17] Ministry of Education and Training. (2016). Swaziland's Curriculum for the 21st Century. Curriculum Framework. Discussion Document. Mbabane: Swaziland Government. 
[18] Moss, P. (2008). Sociocultural Implications for the practice of assessment 1: Classroom Assessment. In P. Moss, J. Pullin, E. H. Gee, \& L. J. Young, Assessmetn, Equity, and Opportunity to Learn. New York: Cambridge University Press.

[19] Muhonen, H., Rasku-Puttonen, H., Pakarinen, E., Pikkeus, A., \& Lerkkanen, M. (2016). Scaffolding through dialogic teaching in early school classrooms. Teaching and Teacher Education, 55, 143-154.

[20] Ruiz-Primo. (2011). Informal Formative Assessment: The role of instructional dialogues. Studies in Educational Evaluation, 15-24.

[21] Ruiz-Primo, M., \& Furtak, M. (2007). Journal of Research in Science Teaching, 44(1), 57-84.

[22] Sampson, V., \& Blanchard, M. (2012). Science Teachers and Scientific Argumentation: Trends in Views and Practice. Journal of Research in Science Teaching, 49(9), 1122-1148.

[23] Shirley, M. (2009). A Model of Formative Assessment Practice in Secondary Science Classrooms Using An Audience Response System. Unpublished Doctoral Dissertation, Ohio State University, Ohio.

[24] Shute, V. (2008). Focus on Formative Assessment Feedback. Review of Educational Research, 78(1), 153-189.

[25] Tuan, L., \& Nhu, N. (2010). Theoretical Review on Oral Interaction in EFL Classrooms. Studies in Literature and Language, 1(4), 29-48.

[26] UNDP. (2014). Guidelines for Inclusion: Ensuring Access to Education for all. Paris: Author.

[27] UNESCO. (2005). Guidelines for Inclusion: Ensuring Access to Education for all. Paris: Author.

[28] UNESCO. (2015). Education For All 2015 National Review Report: Swaziland. Mbabane: United Nations.

[29] Vygotsky, L. (1978). Mind in Society. Cambridge: Harvard University Press.

[30] Wiliam, D., \& Leahy, S. (2007). A Theoretical Foundation for Formative Assessment. Formative Classroom Assessment Theory into Practice, pp. 29-42.

[31] Wiliam, D., \& Thompson, M. (2007). Integrating Assessment with Instruction: What will it take to make it work? (C. Dwyer, Ed.) The Future of Assessment: Shaping Teaching and Learning, pp. 5382.

[32] William, D. (2011). Here's how teachers can get on-the-spot evidence about what students do and do not understand before moving forward with their lesson. Educational Leadership, 41-44.

\footnotetext{
*Corresponding author.

E-mail address: mzenzi316@ gmail.com / oloyedeoi@ uniswa.sz / vlkelly@ uniswa.sz
} 